Acta medico-historica Rigensia (1999) IV: 425-434

DOI: 10.25143/amhr.1999. IV.31

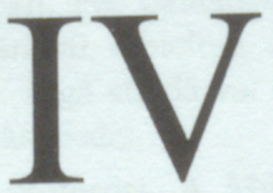



Maija Anže

\section{LATVIJAS MEDICĪNAS VĒSTURNIEKU APVIENĪBAS UN MUZEJA DARBĪBAS PĀRSKATS PAR 1997. UN 1998. GADU}

3. Pasaules latviešu ārstu kongresa laikā 1997. gada 26. jūnijā sakarā ar Latvijas Medicīnas vēsturnieku apvienības prezidenta Dr.med. A. Vīksnas slimošanu par apvienības prezidentu tika ievēlēts profesors A. Miltinšs, par vietnieci - E. Bērziṇa.

Apvienības biedru kopskaits 1998. gada 31. decembrī-44, t.sk. 9 habilitēti doktori, 15 doktori, 5 goda doktori, 2 LZA akadēmiķi, 2 LZA korespondētājlocekli. Pēc pamatspecialitātes 29 apvienības biedri ir ārsti, 5 veterinārārsti, 4 biologi, 2 vēsturnieki, 2 ķīmiķi, 1 filologs un 1 inženieris. Rīgā strādā vai dzīvo 39, citur Latvijā 4, ārzemēs - 1 apvienības biedrs.

1997. gada novembrī profesors A. Miltiņš ievēlēts par LZA korespondētājlocekli. 1998. gada 30. janvārī docentam K. E. Aronam piešķirts LZA goda doktora zinātniskais grāds (Dr.med.h.c.). 1998. gada 13. februārī akadēmiķis J. Stradinsš ievēlēts par LZA prezidentu. 1998. gada 15. jūlijā M. Baltiņš, A. Miltinš̌ un A. Vīksna ievēlēti par valsts profesoriem LU atjaunotajā Medicīnas fakultātē. Sakarā ar maksimālā vecuma sasniegšanu 1998. gada 25. augustā docents K. E. Arons atstājis direktora amatu $A M L$ Medicīnas vēstures institūtā. Par Medicīnas vēstures institūta jauno direktoru ievēlēts Dr.med. J. Salaks, kam 1998. gada oktobrī piešķirts docenta zinātniskais nosaukums.

1997. gada oktobrī docents K. E. Arons iecelts par Starptautiskā biogrāfiju centra Kembridžā Eiropas ǵenerāldirektora vietnieku. Šĩ organizācija gatavo slavenos Who is Who izdevumus.

1998. gada 22. augustā J. Salaks adaptēts par Eiropas Medicīnas zinātņu vēstures muzeju asociācijas (EAMHMS) prezidija locekli. 
Paula Stradiña balva 1998. gadā piešksirta LZA īstenam loceklim $A M L$ profesoram Ilmāram Lazovskim un LZA ārzemju loceklim Stenforda universitātes (ASV) profesoram Kristapam Zariņam. I. Lazovskis tika apbalvots par darbu kopu, kuros apskatiti klīniskās nefroloǵijas pamataspekti, kā arī par medicīnas terminoloǵijas un medicīnas filozofijas izstrādi; K. Zariņš - par pasaules nozīmes pētījumiem miega artērijas patologijā un ieguldījumu Latvijas medicīnas attīstībā.

Baltijas medicīnas vēsturnieku asociācijas prezidents V. Sjūdikas un sekretāre V. Miežutavičiūte 1998. gadā Kauñā aizstāvēja disertācijas medicīnas vēsturē. 1997. gadā Kauņā disertāciju medicīnas doktora grāda iegūšanai aizstāvēja V. Gudiene. Šo disertāciju oponents bija docents K. $\overline{\mathrm{E}}$. Arons, bet V. Sjūdika disertācijas komisijas loceklis - Dr.med. A. Vīksna. 1999. gada janvārī Lietuvā notika Baltijas medicīnas vēsturnieku asociācijas konference (19. Baltijas zinātṇu vēstures konferences ietvaros).

Apvienības biedri piedalījās dažādos zinātniskos kongresos un citos sarîkojumos ārzemēs: 1) 1997. gada jūnijā - R. Vainovska Starptautiskās muzeologu komitejas (ICOFOM) simpozijā Francijā; 2) 1997. gada augustā - S. Savenko Starptautiskajā seminārā Baltkrievijā; 3) 1997. gada septembrī - K. E. Arons Eiropas Medicīnas zinātnu vēstures muzeju asociācijas $(E A M H M S)$ prezidija sēdē Francijā un Berlīnes Brīvās universitātes Medicīnas vēstures institūta apspriedē Vācijā; 4) 1997. gada septembrī - B. Raubiško 14. Starptautiskajā morfologisko zinātnuu kongresā Kīnā; 5) 1997. gada oktobrī R. Lindberga 8. Starptautiskajā antropologu konferencē Igaunijā; 6) 1998. gada jūnijā - K. Ē. Arons un J. Salaks Vācijā, Potsdamā, Ernsta fon Bergmaña Neirologijas klīnikas atklāšanas konferencē, kurā K. E. Arons nolasīja lekciju, bet J. Salaks demonstrēja videofilmu par E. fon Bergmani; 7) 1998. gada augustā K. E. Arons, M. Anže, E. Bērziņa, J. Danusēviča, A. Dirbe, E. Jirgena, R. Lindberga, V. Pundure, J. Salaks, AMLRSU rektors profesors J. Vētra un D. Zole 9. Eiropas Medicīnas zinātṇu vēstures muzeju asociācijas kongresā Lielbritānijā, kur referātus nolasīja E. Bērziṇa (par medicīnisko instrumentu 
darbnīcām Rīgā), E. Jirgena (par oftalmologiskiem instrumentiem muzejā), J. Salaks (par A. Hākena uretroskopu), J. Vētra (par āderciršiem tautas medicīnā), bet ar stenda referātiem uzstājās R. Lindberga un J. Vētra (par vēsturiskiem antropologiskiem instrumentiem) un D. Zole (par pirmo paralelometru); 8) 1998. gada septembrī - K. E. Arons un J. Salaks 36. Starptautiskajā medicīnas vēstures kongresā Tunisijā.

1998. gada 19. novembrī noslēgts sadarbības līgums starp Paula Stradina Medicīnas vēstures muzeju un Valsts veterināro dienestu, lai popularizētu veterinārmedicīnu un tās nozīmi cilvēku veselības aizsardzības jomā.

Lielākie sarîkojumi Rīgā: 1997. gada 22. jūnijā atklāj izstādi "Latviešu ārsti pasaulē" sakarā ar Latviešu Ārstu un zobārstu apvienības 50 gadu jubileju; 1997. gada 26. jūnijā - medicīnas vēsturnieku sekcijas sēde 3 . Pasaules latviešu ārstu kongresā; 1998. gadā no 24. līdz 26. septembrim - starptautiska darba konference "Jauna pieeja medicīnas vēsturei" ("New Approaches in Medical History").

Šajā laikā miruši medicīnas vēsturnieki: 1997. gada 1. janvārī profesors Imants Eglītis (dz. 1938. g.), 1997. gada 15. janvārī Valentīna Proṇina (dz. 1947. g.), 1997. gada 23.aprîlī - LĀB goda biedrs Dr.med. dent. Vladimirs Vigdorčiks (dz. 1909. g.); 1998. gada 2. septembrī - Evelīna Davidsone (dz. 1931. g.), 1998. gada 3. septembrī - Dr.habil.med. Dzintris Alks (dz. 1931. g.). 1998. gadā miruši Paula Stradina balvas laureāti: docents Alfons Kaikaris (dz. 1922. g.) Lietuvā, profesors Anatolijs Georgijevskis (dz. 1908. g.) Krievijā un profesors Heincs Millers-Dīcs (dz. 1923. g.) Vācijā.

1997.gadā mirusi arī ievērojamā latviešu izcelsmes bioloǵe LZA goda locekle Dr. Marta Śtaudingere-Voita (sīkākas ziņas sk. Acta Medico-Historica Rigensia II. - Rìga, 1994. - 287.-300. lpp.) 


\section{H R O N I K A}

$1997^{*}$

22. janvāris. Ž. Karlsona 100 gadiem veltīta apvienības sēde.

1. LZA kor. loc. A. Vīksna. Psihiatrs un rakstnieks Ž. Karlsons.

27. janvāris. N̦. Stradiṇas 100 gadiem veltīti 34. Stradiṇa lasījumi.

1. Koncerts.

2. A. Eglīte. N̦. Stradiñas-Mališevas mācību un darba gadi.

3. LZA akad. I. Lazovskis, LZA goda loc. E. Ezerietis, LZA akad. J. Stradiņš. Atmiņas par N̦. Stradiņu.

4. Jubilejas izstādes apskate.

20. marts. E. Fērmaña 125 gadiem veltīta apvienības sēde.

1. V. Pundure. E. Fērmaṇa dzīve un zinātniskā darbība.

2. Doc. M. Baltinšs. E. Fērmanis un Latvijas Universitāte.

3. Jubilejas izstādes apskate.

3. aprīlis. P. Kalniņa 125 gadiem veltīta apvienības sēde.

1. Dr.hist. Ē. Jēkabsons. Ārsta un valsts darbinieka P. Kalniņa dzīve un darbība.

2. Jubilejas izstādes apskate.

10. aprīlis. S. Reinberga 100 gadiem veltīta apvienības sēde.

1. Prof. J. Nemiro, S. Reinberga dzīve un darbība.

2. V. Raits, B. Apinis, E. Vatere. Atminnas par S. Reinbergu.

3. Jubilejas izstādes apskate.

13. maijs. M. Vovsi 100 gadiem veltīta apvienības sēde.

1. Dr.med. A. Hazanovs. M. Vovsi dzīve un darbs.

2. Jubilejas izstādes apskate.

\footnotetext{
* Hroniku par 1997.gadu sastādījis A. Vikssna 
15. maijs. V. Purmaḷa 70 gadiem veltīta kopsēde ar Latvijas Kirurgu asociāciju.

1. Doc. K.E. Arons. V. Purmalis - vēsture un atminnas.

2. G. Purmalis, R. Plūmina, doc. J. Upmane, B. Jakovels, Dr.med. T. Seglina, A. Draiska, A. Augule. Atminas par V. Purmali.

3. Jubilejas izstādes apskate.

5. jūnijs. H. Kiršentāla 100 gadiem veltīta apvienības sēde.

1. O. Kiršentāls. Tēva dzīve un darbs.

2. Jubilejas izstādes apskate.

12. jūnijs. K. Forlanīni 150 gadiem veltita kopsēde ar Latvijas Tuberkulozes un plaušu slimỉbu ārstu asociāciju.

1. Dr.med. P. Klīdzējs, V. Saulīte. K. Forlanīni dzīve un darbība.

2. Jubilejas izstādes apskate.

26. jūnijs. Medicīnas vēsturnieku sekcijas sēde Trešā pasaules latviešu ārstu kongresā.

1. LZA akad. I. Lazovskis. Medicīnas ētika vēstures un ārsta personības aspektā.

2. Doc. J. Štrauhmanis. Mediḳu devums Latvijas geogrāfiskā izpētē 18. un 19. gs.

3. Doc. M. Baltiňš. Dažas latviešu medicīnas terminologijas veidošanas likumsakarības.

4. Doc. M. Baltiňš. LĀZA "Apkārtraksts" kā Latvijas medicīnas vēstures avots.

5. L. Salaka, R. Radvani (ASV). Pakalpojums zinātnei un cilvēcei.

6. M. Anže. Latviešu Ārstu un zobārstu apvienības arhīvs.

7. E. Bērziña. Triju Zvaigžņu ordenis Latvijas ārstiem (19241940).

8. Dr.med. A. Skutelis, doc. I. Purviňs, Dr.med. S. Jankovskis. Farmakoloǵiskā izglīîiba Latvijā 20, gadsimtā. 
9. Dr.sc.ing. I. Grosvalds, doc. U. Alksnis. LU K̦īmijas fakultātes Farmācijas nodaļa (1919-1940).

10. Prof. I. Meirovics, Dr.sc.ing. I. Grosvalds. E. Zarinšs - augstākās farmaceitiskās izglītības un uzturvielu pētniecỉbas pamatlicējs Latvijā.

11. A. Ruplis, Dr.sc.ing. I. Grosvalds. J. Kupcis - Latvijas minerālūdeñu un dziedniecības dūṇu pētnieks.

12. V. Pundure, A. Dirbe. E. Fērmanim - 125.

13. U. Lapiņš. V. Ozolinšs - psihiatrs un veselības aprūpes vadītājs.

14. Dr.biol.h.c. J. Jākobsons. LU Serumstacijas ieguldịjums biopreparātu ražošanā Latvijā.

15. Prof. H. Voskis. A. Bieziña ieguldījums operatīvā ḳirurgijijā un topogrāfiskā anatomijā.

16. V. Fersters. A. Bieziňš un sporta medicīna Latvijāa .

17. Prof. A. Miltiņš. Daži mediķi - latviešu mākslas meccnāti.

18. R. Lindberga. J. Prīmanis - plastiskās anatomijas profesors Latvijas Mākslas akadēmijā.

19. Dr.biol. B. Raubiško. Preparators J. Poḷikēvičs.

20. Prof. A. Dālmane. Latvijas Anatomu, histologu un embriologu zinātniskās biedrības pirmie 20 darba gadi (1951-1971).

21. I. Kokare, Dž. Krūminna, I. Duljevska. N. Caunas antropoligiskie pētījumi Latvijas armijā 1939. gadā un iegūto datu analīze pēc 57 gadiem.

22. Pārskats par LaMVA darbību.

23. J. Cīrula gleznu izstādes atklāšana.

12. septembris. V. Minca 125 gadiem veltīta kopsê, le ar Listvijas Ķirurgu asociāciju.

1. Piemiņas plāksnes atklāšana pie Bikur Holim slimnīcas ìk.as Rīgā, Maskavas ielā 122/128 (no rīta). 
2. Dr.hab.med. A. Gandzs. V. Minca mūžs un darbība.

3. M. Margolins. V. Minca kirurgiskā darbība Bikur Holim slimnīcā.

4. Prof. Z. Čerfass (Izraēla). Atmiņas par V. Mincu.

5. Jubilejas izstādes apskate.

27. novembris. A. Veinberga 100 gadiem veltita apvienības sêde.

1. LZA kor. loc. A. Vīksna. A. Veinbergs un Latvijas slimokases.

2. Dr.biol. T. Stūre. A. Veinberga izcelsme un dzīve.

3. Dr.hist. R. Grāvere. Ulmaņu dzimtas genealogija un antropologíija.

4. Jubilejas izstādes apskate.

14. decembris. Muzeja dibināšanas 40 gadu atzīmēšana un grāmatas "Acta Medico-Historica Rigensia III" prezentācija.

1. Doc. K.E. Arons. Muzeja 40 gadi.

2. Akad. J. Stradiṇš. Krājuma "Acta Medico-Historica Rigensia" 3. sējums.

3. Apsveikumi.

16. decembris. Veterinārmedicīnas vēsturei veltīta apvienības sēde.

1. Doc. G. Preinbergs. E. Paukuḷa dzīve un darbība.

2. Doc. M. Baltinšs. E. Paukulis un LU Medicīnas fakultāte.

3. Doc. G. Preinbergs. E. Cīrulis un Latvijas Republikas veterinārais dienests.

4. Dr.biol.h.c. J. Jākobsons. A. Kirhenšteina darbība veterinārmedicīnā.

5. Diskusija par veterinārmedicīnas vēstures sekcijas izveidošanu LaMVA sastāvā.

6. E. Paukula jubilejas izstādes apskate. 
19. decembris. V. Rubula 100 gadiem veltīta izbraukuma kopsēde ar Latvijas Farmaceitu biedrïbu Rēzeknē.

1. LZA kor.loc. A. Vīksna. Tautas labklājības ministrs provizors V. Rubulis: dzīves un darba gaita.

2. E. Rubulis, J. Jakovleva. Atmiñas par V. Rubuli.

\section{8}

20. janvāris. 35. Stradiṇa lasījumi.

1. Paula Stradiṇa balvas pasniegšana prof. K. Zariṇam un prof. I. Lazovskim.

2. Prof. J. Volkolakovs. Profesors Kristofers Kristaps Zariņ̌̌.

3. Dr.habil.med. J. Vētra. Profesors Ilmārs Lazovskis.

4. Prof. K. Zariņ̌s. Miega artērijas patologija.

5. Prof. I. Lazovskis. Haosa teorija un fenomenologiska pieeja pacientam.

2. aprīlis. Atklāj izstādi "Dilonis", kas veltīta tuberkulozes apkarošanai Latvijā.

12. maijs. Atklāj starptautisku izstādi "Izpēti sevi" (Corpora Nova) kopā ar Veselības veicināšanas biedrību, Rīgas novada slimokasi un Rīgas Domi.

20. maijs. I. Eglīša 60 gadiem veltīta kopsēde ar Latvijas Psihiatru asociāciju.

1. Doc. R. Andrēziṇa. I. Eglīša dzīve un darbība.

2. Atmiṇu stāstījumi.

3. Izstāde.

3. jūnijs. Mikrobiologa K. Helmaña 150 gadu dzimšanas dienas pasākumi Jelgavā un Tērvetē kopā ar Latvijas Lauksaimniecības universitāti, Valsts Veterināro dienestu, Latvijas Veterinārārstu biedrïbu un Augusta Kirhenšteina Mikrobiologijas un virusologijas institūtu.

7. jūlijs. Doc. K.Ē. Arona grāmatas "Historia medicinae: Compendium" atvēršanas svētki (ar preses pārstāvjiem). 
2. septembris. Atklāj izstādi "Tūra Heijerdāla cel̨ojumi" sakarā ar T. Heijerdāla (Norvēgija) un ārsta J. Senkēviča (Krievija) vizìti Latvijā.

24. septembris. Atklāj starptautisku darba konferenci "Jauna pieeja medicīnas vēsturei".

1. Akad. J. Stradiņš. Uzruna.

2. E. Larsens (Norvēǵija). Apsveikums konferences dalībniekiem.

5. oktobris. Piedalīšanās ārsta R. Čakstes atceres vakarā Jelgavas pilsētas slimnīcā.

9. oktobris. A/s "Grindex" pasniedz D. H. Grindela medaļu Farmācijas muzeja speciālistam Latvijas Farmaceitu biedrỉbas prezidentam A. Eniñam u.c. laureātiem.

16. oktobris. E. Apses-Apsīša 100 gadiem veltīta kopsēde ar Latvijas Kosmētiķu un kosmetologu asociāciju.

1. Prof. A. Miltinš̌. Ernesta Apses-Apsǐša dzīves gājums.

2. I. Stepanova. Skaistumkopšana un kosmetologijas sākumi un attīstība Latvijā.

3. Prof. H. Voskis. Atmiņas par skolotāju un ārstu kosmetologu.

4. Izstāde.

22. oktobris. Atskaites sēde par komandējumiem uz Angliju un Tunisiju.

1. Doc. K. E. Arons. 36. Starptautiskais medicīnas vēstures kongress Tunisā.

2. Prof. J. Vētra. 9. Eiropas medicīnas muzeju asociācijas kongress Līdsā.

3. V. Pundure. Iespaidi par medicīnas muzejiem Londonā.

4. Materiālu un fotoattēlu apskate.

24. oktobris. Piedalīšanās pieminekḷa atklāšanā Latvijas slimokasu vadītājam A. Veinbergam Juglas kapos. 
6. novembris. Atklāj izstādi "Latvijas Sarkanajam Krustam - 80" 6. novembris. E. Renča un V. Mīlenbaha 100 gadiem veltīta apvienības sēde.

1. Prof. M. Baltinšs. Divu LU mācībspēku farmakologa E. Renča un higiēnista V. Mīlenbaha simtgade.

2. Atmiṇu stāstījumi un diskusijas.

3. Izstāde.

17. novembris. Atklāj izstādi "Augstākās medicīniskās izglītības pirmsākumi Latvijā" sakarā ar Latvijas valsts proklamēšanas 80. gadadienu.

15. decembris. Veterinārārsta $\bar{A}$. Herteļa atcerei veltīta kopsēde ar Latvijas Veterinārārstu biedrību.

1. Dr.philol. G. Grīnuma. Rainis un Ā. Hertela dzimta.

2. Doc. G. Preinbergs. Veterinārārsts $\bar{A}$. Hertelis - Aizputes kara vadonis.

3. A. Fokins. Par Ā. Hertela piemiñas saglabāšanu Rīgā.

4. Debates.

Svarīgākās publikācijas 1997. un 1998. gadā

Acta Medico-Historica Rigensia. - Rīga, 1997. - Vol.3. 477 lpp.

Arons K. $\bar{E}$. Historia medicinae: Compendium. - Rīga, 1998. 358 lpp.

Miltiņš A., Miltiņ̌̌ V. (sast.). Pēteris Sniḳers. - Rīga, 1998. 113 lpp.

Stradiņ̌ J. Latvijas Zinātṇu akadēmija: izcelsme, vēsture, pārvērtỉbas. - Rīga, 1998. - 711 lpp.

Vīksna A. Profesors Imants Eglītis. Biobibliogrāfiskais rādītājs. Rīga, 1998. - 68 lpp.

Vǐksna A. (sast.). Latvijas medicinas jubilejas: 1998. - Rīga, 1997. 31 lpp. 